\title{
Specialistische ondersteuning in de basiszorg voor jeugd
}

\author{
Fieke Raaijmakers · Mariska Klein Velderman
}

Published online: 19 August 2020

(C) The Author(s) 2020

Samenvatting Sinds de inwerkingtreding van de nieuwe Jeugdwet (2015) zijn verschillende lokale initiatieven ontstaan voor het realiseren van de transformatiedoelstellingen rond passende hulp. In de gemeenten Nijmegen en Renkum werden hiertoe een Specialistisch Ondersteuner Jeugdgezondheidszorg en een Gedragswetenschapper Jeugd ingezet. Deze initiatieven zijn opgestart om de signalering en verwijzing van psychosociale en gezinsproblematiek in de basiszorgvoorzieningen te verbeteren. Dit artikel beschrijft de resultaten van een evaluatieonderzoek dat in 2019 is afgerond.

Trefwoorden preventie jeugdgezondheidszorg • geestelijke gezondheid - sociaal domein - gemeenten · Jeugdwet

Abstract This article presents results of an evaluation of two local initiatives to support preventive youth healthcare services. Youth mental health specialists were appointed by the municipalities of Nijmegen and Renkum with the aim of 1) strengthening collaboration within the social domain (i.e., school, youth mental healthcare, social team, general practitioners); 2) triage; identification of problems and referral to suitable family support or youth mental health care when needed; 3) offering short term support of parents and children (0 to 18 years old). Information on these specialists' clients, their activities and referrals,

F. Raaijmakers, MSc $(\bowtie)$

Eerstelijnsgeneeskunde, Academische werkplaats AMPHI, Radboudumc, Nijmegen, Nederland

fieke.raaijmakers@radboudumc.nl

Dr. M. Klein Velderman

Child Health, TNO, Leiden, Nederland and recommendations for future implementation is presented.

Keywords preventive youth healthcare $\cdot$ mental health $\cdot$ social domain - municipalities $\cdot$ Youth Act

\section{Inleiding}

Sinds de decentralisatie zijn gemeenten verantwoordelijk voor alle vormen van zorg aan jeugdigen en staan zij voor de taak om deze zorg te vernieuwen, te transformeren. Een jaar na het in werking treden van de wet bleek dat op de samenwerking in het jeugdveld nog het nodige aan te merken was [1, 2]. Het leek erop dat de mate waarin psychische of psychosociale problemen in de basiszorg gezien werden en de mate waarin passende specialistische zorg hiervoor werd ingezet, nog niet goed op elkaar aansloten. Er zijn verschillende initiatieven ontstaan om de transformatiedoelstellingen te realiseren en er zodoende voor te zorgen dat er op tijd en zo integraal mogelijk meer passende hulp wordt geleverd.

Zo kozen steeds meer gemeenten ervoor een vorm van specialistische ondersteuning in te zetten in basiszorgvoorzieningen, bijvoorbeeld in de jeugdgezondheidszorg of huisartsenpraktijk. In 2018 publiceerde dit tijdschrift een artikel over zeven van dergelijke initiatieven ter versterking van de jeugdgezondheidszorg [3]. Twee hiervan betroffen de gemeenten Nijmegen en Renkum. Om de signalering en verwijzing van psychosociale en gezinsproblematiek in de basiszorgvoorzieningen te verbeteren en de verbinding te maken tussen professionals (jeugdgezondheidszorg, huisarts, sociaal wijkteam, onderwijs en jeugd-ggz) kozen deze gemeenten voor respectievelijk de inzet van een Specialistisch Ondersteuner Jeugdgezondheidszorg (SOJ) en Gedragswetenschapper Jeugd ter ondersteuning van huisartsen. 
Figuur 1 Verwijzingen door de SOJ (informatie over $n=19$ ) en Gedragswetenschapper Jeugd $(n=133)$, percentages
Verwijzing SOJ

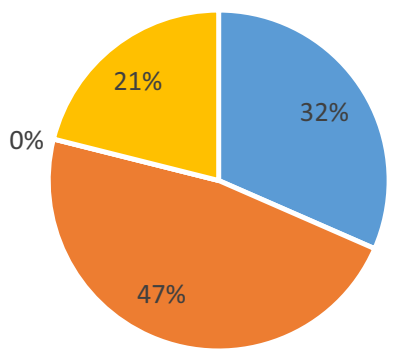

Verwijzing Gedragswetenschapper Jeugd

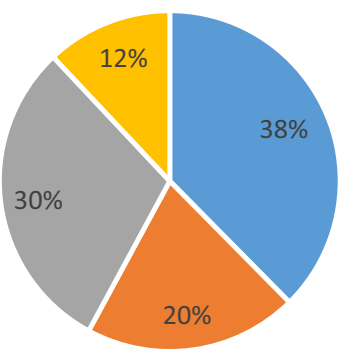

- Geen verwijzing

- Specialistische-GGZ

- Generalistische basis-GGZ

Overige verwijzing
In 2019 is een evaluatieonderzoek (ZonMw-project 736200013) afgerond dat inzicht geeft in de cliënten, het cliëntcontact en verwijzingen, en succesfactoren en aandachtspunten voor implementatie van betreffende werkwijzen [4].

\section{De Specialistisch Ondersteuner Jeugdgezondheidszorg en Gedragswetenschapper Jeugd}

De SOJ en Gedragswetenschapper Jeugd richten zich op psychosociale en gezinsproblematiek en vervullen drie taken:

1. verbinding maken tussen professionals;

2. triageren en toeleiden naar passende psychosociale ondersteuning en gezinshulp;

3. ouders en jeugdigen ( 0 tot en met 18 jaar) kortdurend begeleiden.

De SOJ-inzet bestond uit twee professionals met ieder een aanstelling van 4 uur per maand. Beide SOJ hadden een aanstelling bij Karakter Kinder- en Jeugdpsychiatrie en waren gepositioneerd op consultatiebureaus in twee sociaal zwakkere wijken. Doel was om waar nodig de expertise op het terrein van de jeugd-ggz in de eerste lijn te versterken en de indicatiestelling te verbeteren voor verwijzing naar specialistische zorg. De SOJ waren voornamelijk een vraagbaak voor jeugdartsen en jeugdverpleegkundigen die vragen en zorgen hadden over jonge kinderen (0 tot en met 4 jaar). De SOJ gaven beperkt zelf begeleiding aan ouders en kinderen - de positionering en beperkte capaciteit boden hier weinig ruimte voor.

De Gedragswetenschapper Jeugd werd door twee professionals opgestart met een functieomvang van totaal 1 fte. De Gedragswetenschapper Jeugd werkte in opdracht van de gemeente en was aangesteld bij GGD Gelderland-Midden. De Gedragswetenschapper Jeugd verrichtte haar werkzaamheden op verschillende locaties, bijvoorbeeld in een ruimte van de gemeente, maar ook op consultatiebureaus. Doel was kinderen tot en met 18 jaar laagdrempelig en snel goede hulp te bieden met betrekking tot ontwikkeling, gedrag en opvoeding. De Gedragswetenschapper Jeugd was in eerste instantie vooral een vraagbaak voor huisartsen. In de loop van het traject bleek dat andere belanghebbenden (zoals het sociaal team) de Gedragswetenschapper Jeugd ook steeds beter wisten te vinden. De positionering en capaciteit van de Gedragswetenschapper Jeugd gaven, meer dan bij de SOJ het geval was, ruimte voor het bieden van begeleiding aan ouders en jeugdigen.

\section{Cliënten, cliëntcontact en verwijzingen}

De SOJ zagen in een periode van anderhalf jaar (2018-2019) 36 jeugdigen: 22 jongens en 14 meisjes. De kinderen waren gemiddeld 3,4 jaar oud en waren verwezen vanuit de jeugdgezondheidszorg. De Gedragswetenschappers Jeugd zagen in een periode van twee jaar (2017-2018) 133 jeugdigen: 67 jongens en 66 meisjes. Deze jeugdigen waren gemiddeld 10,5 jaar oud en vooral door huisartsen verwezen naar de Gedragswetenschapper Jeugd.

De problematiek van jeugdigen die de SOJ bezochten leek gemiddeld zwaarder te zijn dan van jeugdigen die contact hadden met de Gedragswetenschapper Jeugd. Bij aanvang werd de problematiek van de kinderen door de SOJ overwegend als matig tot zwaar ingeschat. De problematiek is door de Gedragswetenschapper Jeugd bij aanvang in twee derde van de gevallen als matig ingeschat $(n=90 ; 68 \%)$. Negentien jeugdigen (14\%) hadden bij het eerste contact met de Gedragswetenschapper Jeugd lichte problemen, bij 24 jeugdigen (18\%) werd de problematiek als zwaar ingeschat.

De meest voorkomende ingangsklachten van kinderen bij de SOJ betroffen ontwikkelingsproblemen of hadden betrekking op de sociale interactie en/of non-verbale communicatie. De Gedragswetenschapper Jeugd zag jeugdigen het meest vanwege problematiek rond angst/dwang en/of stemming. Begeleiding door de SOJ bestond meestal uit één of twee contacten, bij de Gedragswetenschapper Jeugd ging het om gemiddeld drie contacten. Bij beide initiatieven lag de focus vooral op triage/screeningsdiagnostiek en kortdurende ondersteuning. Ongeveer twee derde van de jeugdigen werd door de SOJ en Gedragswetenschapper Jeugd doorverwezen naar andere vormen van ondersteuning. Voor ongeveer de helft betrof het verwijzingen naar de ggz. Bij de SOJ ging het uitsluitend 
om specialistische-ggz, bij de Gedragswetenschapper Jeugd ook om basis-ggz (zie fig. 1).

Ook bij afronding van de trajecten zijn de Gedragswetenschappers Jeugd gevraagd naar de ernst van de problemen (deze informatie is niet beschikbaar van de SOJ). De ernst leek na de contacten met de Gedragswetenschappers Jeugd verminderd. Waar de problematiek bij aanvang door de Gedragswetenschappers Jeugd overwegend (68\%) als matig werd ingeschat, is dit op de nameting nog voor 59 jeugdigen (44\%) het geval. Er zijn na afronding meer jeugdigen met lichte problemen: $41 \%(n=55)$, in vergelijking met $14 \%$ van de jeugdigen bij aanvang van de begeleiding. De ernst van de problematiek werd bij afronding nog voor 19 jeugdigen (14\%) als zwaar ingeschat (vergeleken met $18 \%$ bij aanvang).

\section{Succesfactoren}

Ter evaluatie van de SOJ en Gedragswetenschapper Jeugd is gesproken met 24 belanghebbenden van het primair en voortgezet onderwijs, huisartsen, JGZ-medewerkers, het sociaal team, en medewerkers van de jeugd-ggz en de gemeente Renkum. De professionals die hebben samengewerkt met de SOJ of Gedragswetenschapper Jeugd waren positief en zagen de meerwaarde van een dergelijke professional voor jeugdigen, hun ouders en professionals. De SOJ en Gedragswetenschapper Jeugd voorzien daarmee in een behoefte in situaties waarin de samenwerking tussen professionals tot stand is gekomen en op een goede manier verloopt. De belangrijkste meerwaarde is volgens de betrokkenen:

- voor jeugdigen en ouders: verlagen van de drempel naar de jeugd-ggz, het verminderen dan wel oplossen van problemen en het creëren van lucht in het gezin;

- voor professionals: ondersteuning bij de poortwachtersrol en de mogelijkheid om tijdig door te verwijzen naar de meest passende instantie.

Uit de verschillende gesprekken kwam naar voren dat het voor een goede samenwerking belangrijk is dat de betrokkenen elkaar kennen en ontmoeten. De professionals die niet (veel) samenwerkten met de SOJ of Gedragswetenschapper Jeugd, en hen dus ook niet ontmoetten, misten de functie niet en leken zich zorgen te maken over in hun beleving (onnodige) extra schakels.

Uit de interviews komen de volgende succesfactoren van de SOJ naar voren:

- In het kader van vroegsignalering is het nuttig om de expertise van de SOJ op het consultatiebureau in te zetten. Eventuele problemen bij kinderen kunnen daardoor vroeger worden gesignaleerd, en niet pas wanneer ze op school (ook) vastlopen.

- Met de positionering van de SOJ kunnen medewerkers van de JGZ en de SOJ elkaar ontmoeten en zaken op een laagdrempelige manier met elkaar afstemmen. Voor ouders werkt de positionering op het consultatiebureau drempelverlagend richting de hulpverlening van de jeugd-ggz.

Ook met betrekking tot de Gedragswetenschapper Jeugd worden succesfactoren genoemd:

- De Gedragswetenschapper Jeugd is een laagdrempelige voorziening. Ouders en jeugdigen kunnen door de huisarts, jeugdarts of het wijkteam naar de Gedragswetenschapper Jeugd worden verwezen, maar het staat ouders en jeugdigen ook vrij om de Gedragswetenschapper Jeugd zelf te benaderen. Dit is belangrijk in het kader van preventie.

- De Gedragswetenschapper Jeugd is in de gelegenheid om snel te reageren en te handelen. Hierdoor kan verergering van de problemen worden voorkomen (waarmee ook de inzet van zwaardere ondersteuning niet nodig is) en kunnen eventuele wachttijden worden overbrugd (waarmee de situatie beter onder controle is en verslechtering kan worden voorkomen). Ouders zijn tevreden over het snelle handelen van de Gedragswetenschapper Jeugd. Dit brengt een kwaliteitsverbetering in het sociaal domein met zich mee.

De gemeente Renkum heeft besloten om de inzet van de Gedragswetenschapper na afronding van de evaluatie op dezelfde manier voort te zetten. De gemeente Nijmegen besloot na afronding van de pilot (juni 2019) niet verder te gaan met de inzet van de SOJ. Per september 2019 startte de gemeente eerst een 'Onderzoek Versterkingskansen keten Jonge Kind', gericht op goede signalering van zorgpeuters, begeleiding naar externe zorg en een doorgaande leerlijn naar het basisonderwijs (Gelijke Kansen Alliantie, september 2019).

\section{Tot slot}

Op basis van de evaluatie is het niet mogelijk om uitspraken te doen over wat een optimale invulling is van een functie als die van de SOJ of Gedragswetenschapper Jeugd. Er kan ook geen antwoord worden gegeven op de vraag welke variant tot de beste resultaten leidt. Wel kan informatie over cliënten, werkzaamheden en verwijzingen uit dit onderzoek gemeenten input geven voor het maken van afwegingen over het inzetten van een vergelijkbaar aanbod in de eigen gemeente.

Tijdens een gesprek met de gemeente Renkum (deze informatie is niet beschikbaar over de gemeente Nijmegen) kwamen ten slotte de volgende lessons learned en implementatieadviezen naar voren:

- Neem de tijd wanneer voor een dergelijke functie wordt gekozen. Het kost tijd voordat de verschillende partners elkaar voldoende kennen, inzicht hebben in elkaars expertise, kennis en werkzaamheden, en de meerwaarde hiervan inzien. 
- Formuleer vooraf doelen, maar leg geen kritische prestatie-indicatoren en dergelijke vast. Deze functie heeft ruimte nodig om te ontstaan en moet recht doen aan de lokale situatie en context.

- Kies bewust hoe en waar je een dergelijke functie positioneert, dit heeft namelijk effect. In de gemeente Renkum is gekozen om deze bij de GGD onder te brengen, omdat deze, anders dan de gemeente, een onafhankelijke positie inneemt. Bij de gemeente lag de nadruk ook meer op een laagdrempelige voorziening. Daarom is bijvoorbeeld niet gekozen voor positionering bij een jeugd-ggzorganisatie.

- Bepaal expliciet welke achtergrond passend is. In de gemeente Renkum is bewust gekozen voor mensen met een achtergrond als SPV'er/orthopedagoog of psycholoog, en niet voor een arts. De motivatie hierbij was dat ze graag aanvullende en complementaire kennis en expertise van een professional met een brede blik wilden inbrengen.

Open Access This article is licensed under a Creative Commons Attribution 4.0 International License, which permits use, sharing, adaptation, distribution and reproduction in any medium or format, as long as you give appropriate credit to the original author(s) and the source, provide a link to the Creative Commons licence, and indicate if changes were made. The images or other third party material in this article are included in the article's Creative Commons licence, unless indicated otherwise in a credit line to the material. If material is not included in the article's Creative Commons licence and your intended use is not permitted by statutory regulation or exceeds the permitted use, you will need to obtain permission directly from the copyright holder. To view a copy of this licence, visit http://creativecommons.org/licenses/by/4.0/.

\section{Literatuur}

1. Yperen T van, Wijnen B, Hageraats R. Evaluatie Jeugdwet. Meer kwaliteit en minder zorgen. Utrecht: Nederlands Jeugd Instituut; 2016.

2. Rooijen M. Samen om het kind: de handen ineen voor specialistische jeugdhulp. Utrecht: Nederlands Jeugd Instituut; 2017.

3. Theunissen MHC, Dijkshoorn J, Klein Velderman M. Tijdschr Gezondheidswet. 2018;96:354.

4. Klein Velderman M, Raaijmakers F, De Lijster-van Kampen GPA, et al. Specialistische ondersteuning in de basiszorg voor jeugd: evaluatie van de inzet van gedragswetenschappers in Renkum en specialistisch ondersteuners jeugdgezondheidszorg in Renkum. TNO Rapport-R11135. Leiden: TNO Child Health;2019. 